Małgorzata Krzemińska-Adamek, Maria Curie-Sklodowska University, Poland Izabela Jarosz, Maria Curie-Sklodowska University, Poland Anna Kiszczak, Maria Curie-Sklodowska University, Poland

DOI:10.17951/Ismll.2021.45.3.1-2

\title{
From the Editors
}

The COVID-19 outbreak has brought several problems and challenges in the educational sector throughout the world. Notwithstanding several obstacles caused by the pandemic, advanced technology has allowed continuing the process of education, yet in a substantially altered version. To be precise, the communication between the teacher and students has been reduced to using online tools and applications without traditional face-to-face contact. The current volume presents the influence of technology-mediated communication on teaching and learning during the pandemic as well as the ways to improve these processes. It is aimed to outline both positive and negative aspects of online communication in teaching and learning, particularly highlighting teachers' and students' reflections, the application of specific teaching techniques, language assessment, teaching language skills and subsystems, and the relevance of non-verbal aspects of communication.

The first two articles discuss emotions experienced during the pandemic by EFL teachers (Katarzyna Papaja) and ways of dealing with the difficulties of lockdown using the storytelling technique (Anna Pełczyńska). The following two articles tackle the issues related to language assessment: the use of an online platform for reduced redundancy testing (Wojciech Malec) and challenges in online assessment leading to revisiting language assessment courses in teacher training programmes (Ferit Kilıçkaya). The remaining texts in the volume concentrate on technology in developing speaking skills in the context of English for Specific Purposes courses (Agnieszka Dzięcioł-Pędich and Agnieszka Dudzik), applica-

Małgorzata Krzemińska-Adamek, Katedra Językoznawstwa Angielskiego i Ogólnego, Instytut Neofilologii, Uniwersytet Marii Curie-Skłodowskiej, PI. Marii Curie-Skłodowskiej 4a, 20-031 Lublin, malgorzata.krzeminska-adamek@mail.umcs.pl,https://orcid.org/0000-0003-2461-2397

Izabela Jarosz, Katedra Językoznawstwa Angielskiego i Ogólnego, Instytut Neofilologii, Uniwersytet Marii Curie-Skłodowskiej, PI. Marii Curie-Skłodowskiej 4a, 20-031 Lublin, Phone: 0048815372799, izabela.jarosz@mail.umcs.pl, http://orcid.org/0000-0002-0543-9595

Anna Kiszczak, Katedra Językoznawstwa Angielskiego i Ogólnego, Instytut Neofilologii, Uniwersytet Marii Curie-Skłodowskiej, PI. Marii Curie-Skłodowskiej 4a, 20-031 Lublin, kiszczak.anna@gmail.com, https://orcid.org/0000-0002-9394-3782 
tions of a pronunciation database in various contexts including home schooling (Robert Skoczek and Alexandra Ebel), and focusing on aspects of Intercultural Communicative Competence while working online with young language learners (Izabela Jarosz, Anna Kiszczak and Małgorzata Krzemińska-Adamek).

The editors believe that the current volume will inspire both scholars and practitioners to reflect on the complexity of technology-mediated communication in the times of the pandemic. 